Asmaa Elmortada,

Ph.D., Cadi Ayad University, Morocco

Chams-Eddoha Mokhlis,

Ph.D., Professor, Hassan II University, Morocco

Ahmed Mokhlis,

Ph.D., Professor, Cadi Ayad University Morocco

Said Elfezazi,

Ph.D., Professor, Cadi Ayad University, Morocco

\title{
INNOVATIONS IN HR MANAGEMENT: A CONTENT ANALYSIS APPROACH
}

Abstract. One of the objectives of human resource management (HRM) is to promote the satisfaction of both managers and employees regarding HRM practices. Since promoting satisfaction begins by assessing its current level, this study aims to analyse the challenges faced by industrial companies' managers within developing countries - such as Morocco- in terms of implementing human resource (HR) function practices. This paper presents then a practice-oriented study conducted using a qualitative method based on the content analysis approach. Thus, data collection was based mainly on semi-structured interviews to which 30 managers had participated. Indeed, this study aims to measure managers' satisfaction regarding the HR function while highlighting, at the same time, the practices used in motivation, documentation process, etc., and in terms of locating weaknesses and obstacles to better HRM. The validity of inquiry was tested and proven by two validation strategies: member checking and external audits strategies. The results found, revealed genuinely remarkable weaknesses. Indeed, it turned out to be a lack consistent in terms of the proper structuring of the HR function. In addition to the poor mastery and application of basic HRM practices, namely the primitivity of documentation processes, and the job-person inadequacy, especially in the scarcity of adoption of developed management methods such as the implementation of provisional management of jobs and skills, the establishment of an occupational health system, and maturity in terms of carrying out the tasks of the control system, or even as regards the weaknesses linked to the lack of active communication, to the clarity of the objectives targeted for all the members, and to the sharing of private information, in addition to those arising from the irrelevance of the training received by the staff. As for proposing solutions, the integration of IT tools could improve the performance of HR management processes. Indeed, information systems promote active communication, different storage data that develop the quality of the decision. They also facilitate managing administrative issues, communicating and applying procedures, programming relevant training and motivating employees. The study has important implications for HR professionals and strategic leaders that are especially interested in developing countries.

Keywords: human resources management, HR function, content analysis, industrial companies, Morocco, job satisfaction, the performance of HR function, IT tools integration, information systems, knowledge-based systems, human-computer interaction.

Introduction. Since old times; for spiritual, materialistic, philosophical or purely scientific reasons. Satisfaction has been the goal sought by everyone. Today, in the middle of an economic environment increasingly complex and competitive, satisfaction is a concept even more related to the discipline of human resource management (HRM), particularly within industrial enterprises. Indeed, people (managers, employees, or State officials) always talk about staff satisfaction effect on a company's performance and thus on the country's prosperity. This belief stems from the growing demand for work quality in today developed world, especially with researches and studies confirming the close link between the psychological side and one's performance (Wang et al., 2014). When an employee looks for satisfaction in terms of working conditions, salary, leadership. HR manager seeks both, minimizing problems that negatively affect business activity such as absenteeism, training, turnover and creating a likely environment to promote employees profitability because «an essential element of the organizations is based on the willingness of people to contribute their efforts in a cooperative system ...»Chester

Cite as: Elmortada, A., Mokhlis, C.-E., Mokhlis, A. \& Elfezazi, S. (2020). Innovations in HR Management: a Content Analysis Approach. Marketing and Management of Innovations, 1, 182-191. http://doi.org/10.21272/mmi.2020.1-14 
Barnard (1938). Convinced that any work, including HRM, cannot lead to best results without the integration of all its stakeholders, it is better to deal the current situation by starting with practitioner's opinion because this «may help HR departments to be even more effective in their business!» as stated Louarn \& Wils (2001). Consequently, this research is a practice-oriented study that aims to reveal challenges faced by HR managers within developing countries through studying the Moroccan context. In order to address managers' satisfaction in-depth, a qualitative research method (Content analysis method) was used because it allows better «understanding the meaning of decisions and behaviours (Usunier, 1993). It is contextual, powerful and robust (Wacheux, 1996)».

Literature Review. Inspired by the concept of «internal customer» developed by Berry (1981), managers and decision-makers have also been considered as internal customers that the company must take care to satisfy so that they can deliver better service. (Heskett et al., 1994), primarily that the performance of the target company through employee satisfaction can only be evaluated by revealing the judgment of managers before it is reflected as a quantified economic return.

Within the framework of this ultimate vision, several researchers were interested in the satisfaction of decision-makers regarding management control. Laitinen (2004), for example, stated that the quality of management control must be strictly linked to the satisfaction of managers. Thus, meeting the information needs of managers influences positively the relevance of their decisions. The relational side between managers and employees was, of course, also developed. In the context of this, Purcell et al. (2003) reported that managers' behaviour strongly influences employee attitudes: «it is also one of the most important factors in developing organizational commitment». Interested in the same theme, Mellahi \& Wood (2003) insisted on respecting some ethics within the company that promote employee satisfaction, his performance (Edmans, 2011), his efficiency within his teams (Derue et al., 2010), or his influence on the team itself (Hackman, 2012). So in this philosophy, « HRM in the structure/systems perspective promotes employee participation and informed choice by staff, with open channels of communication to management aimed at building employee trust and commitment» as «[it will] help line managers carry out their HR/people management and development activities effectively, and support line managers in getting the most out of the people resources» (Farnham, 2010).

Whether for managers or employees, in the last decade, the concept of «job satisfaction» has started to take a multidimensional approach. Indeed, Mignonac et al. (2004) are convinced that job satisfaction is a construct based on an affective component (which takes into account the subject motivations), a conative component (linked to the subject's behaviour, it reveals his passage to action) and a cognitive component (relating to the mechanisms of thought, beliefs and knowledge of the subject). Based on the latter's work, Meyssonnier and Roger (2006) believe that job satisfaction can be treated according to three approaches: as a dynamic, as an assessment, and as an emotional state. Within the framework of this, the thoughts of Meyssonnier and Roger come in perfect adequacy with Igalens (1999) when he defines job satisfaction as being a positive emotional response resulting from the evaluation of work or work experience. Satisfaction is a dynamic concept. It is an unstable perception which evolves according to experiences but also according to the expectations of the employee, which can change throughout his life. (Igalens, 1999) This definition remains close to that given by IGLESIAS et al., (2010) who also took over the work of Mignonac (2004). Patterson et al. (2010) have a similar idea. Indeed, they consider job satisfaction as an interaction between cognition and affect (or reflection and feelings), which can be studied concerning several dimensions, namely pay, co-workers, hierarchy and depending on the job itself. Iglesias et al., (2010) also underlined the existence of links that the job satisfaction can have with other concepts of HRM, in particular with organizational involvement, where the employee is subject to the effect of the organizational commitment (his level of loyalty to the entire organization) instead of being affected only by his positive feeling (satisfaction) towards his job (Price, 2001). Although it has been the subject of more than 10,000 studies carried out since the 1930s (IGLESIAS et al., 2010), job satisfaction remains a source 
of much research and discussion. Indeed, nowadays, one distinguishes more its relation with the performance of the employee Edmans (2011), the effectiveness of this one within the team (Derue et al., 2010), or still its influence on the efficiency of the entire team (Hackman, 2012).

Methodology and Research Methods. According to Dul and Hak (2007), studies can be classified into two categories: Theory-oriented studies that aim to contribute to theory development, and practiceoriented studies that aim to develop knowledge about the improvement of practices. Descriptive practiceoriented research is conducted when it is not necessary to find and test a hypothesis. However, if the practitioner needs knowledge, hypothesis-building practice-oriented research should be performed while hypothesis-testing practice-oriented research is carried out when a hypothesis is available, but it should be tested. This study is a practice-oriented study that aims to present useful information that can be applied to improvement projects. Since this research undertakes to describe and interpret managers' opinions regarding HR function, it is a descriptive study. As recommended by Creswell (2007) to build validity in qualitative researches, there were adopted two of his recommended validation strategies: member checking and external audits strategies. In the member checking strategy, the researcher solicits participants to give their opinions regarding the credibility of research findings and interpretations. This technique is considered as being the essential method to ensure research validity. It was adopted by a large number of researchers (Ely et al., 1991; Glesne et al., 1992; Lincoln et al., 1985; Sharan, 1998; Miles et al., 1984; Jamshidian et al., 2016). In the external audit method, an external consultant or auditor is asked to examine findings, interpretations and conclusions. This auditor should have no connection to the study. This method was also widely used by several researchers (Lincoln et al., 1985; Sharan, 1998; Miles et al., 1984; Jamshidian et al., 2016). In the present inquiry, a private HR consultant and two HR experts admitted the credibility research outcomes. They even recommend for us to check matching findings in other researches that some of them were advocated in the discussion session.

As part of the investigation, the Chamber of Commerce and Industry was visited, which allowed us to have a database containing details of several leaders. We also visited some centres of national unions and managers' associations, in addition to personal contacts. Thus, setting appointments was generally made by phone or by mail, according to the available coordinates. Respondents were selected using a reasonable choice sampling (Thietart, 2003), mainly based on their job title (A Senior Management Member). These respondents were asked to recommend us to other respondents according to the principle of the snowball sampling method. The snowball sampling involves asking interviewees to propose us, other people, that fit the profile required for the investigation, according to the chosen criteria of selection, and that it would be possible to interview. Despite the difficulties encountered to reach interviewees - with specific profiles (General Directors, HR Directors, ...) - that would accept to participate in the survey, it was not tried to have as participants as possible only. However, it has also ensured that the sample is determined following the principle of theoretical saturation (Thietart, 2003) where the sample size is considered optimal when the study stops raising new elements.

Thus, a total of 30 persons with various backgrounds participated in this study. Table 1 describes the characteristics of the participants in this survey. It constitutes a total of 499 years of vocational experience of highly educated participants that $63 \%$ of them are working in very large and subsidiaries of multinational companies. It is a sample of experts and practitioners of HR management.

Talking about interviewing and data analysis procedure, this study uses semi-structured interviews. It is a type of interviews that ensures reliability and high precision, as it allows a better structuring of the debate, especially in the presence of several articles to cover.

The interviews lasted 75 minutes on average. Interviews were passed in different ways. Some of them took places in the company's offices, quietly, ensuring both the smooth running of discussions and subject confidentiality. 
Table 1. Sample characteristics

\begin{tabular}{|c|c|c|c|c|c|c|}
\hline $\mathbf{N}^{\circ}$ & Sex & Position & Education & $\begin{array}{c}\text { Experience } \\
\text { (years) }\end{array}$ & $\begin{array}{l}\text { Company } \\
\text { size }\end{array}$ & Activity \\
\hline $\mathrm{P} 1$ & $\mathrm{M}$ & Engineer & Industrial Engineering & 10 & VLC & Agribusiness \\
\hline P2 & M & Director & Industrial Engineering & 22 & SMC & $\begin{array}{l}\text { Building / } \\
\text { Construction }\end{array}$ \\
\hline P3 & M & Director & Master's degree & 35 & $\begin{array}{c}\text { VSC } \\
\text { (subsidiary) }\end{array}$ & Mining \\
\hline P4 & M & $\begin{array}{c}\text { Personnel department } \\
\text { manager }\end{array}$ & $\begin{array}{c}\text { Bachelor's degree } \\
(\mathrm{Bac}+3)\end{array}$ & 12 & $\mathrm{MC}$ & $\begin{array}{c}\text { Building / } \\
\text { Construction }\end{array}$ \\
\hline P5 & $\mathrm{F}$ & $\begin{array}{l}\text { Administrative } \\
\text { Executive }\end{array}$ & $\mathrm{Bac}+4$ & 23 & MC & Agribusiness \\
\hline P6 & $\mathrm{F}$ & HR Assistant Manager & Master's degree & 15 & VLC & Energetics \\
\hline P7 & $M$ & Logistics Manager & Ph.D. & 14 & VLC & Metalurgy \\
\hline P8 & $\mathrm{M}$ & Production Supervisor & Engineer & 4 & SMC & Automotive \\
\hline P9 & $\mathrm{M}$ & HR Director & Ph.D. & 20 & VLC & Textile \\
\hline P10 & $\mathrm{F}$ & Quality manager & $\mathrm{Bac}+4$ & 12 & VLC & Agribusiness \\
\hline P11 & $\mathrm{F}$ & Entrepreneur & $\mathrm{Bac}+2$ & 10 & SC & Textile \\
\hline P12 & M & $\begin{array}{l}\text { Maintenance } \\
\text { Supervisor }\end{array}$ & Engineer & 4 & SMC & $\begin{array}{l}\text { Building / } \\
\text { Construction }\end{array}$ \\
\hline P13 & $\mathrm{M}$ & Sales manager & Master's degree & 29 & VLC & Agribusiness \\
\hline P14 & $\mathrm{M}$ & Leader & $\mathrm{Bac}+4$ & 32 & SMC & Mining \\
\hline P15 & M & Engineer & Engineering & 2 & SC (subsidiary) & $\begin{array}{l}\text { Building / } \\
\text { Construction }\end{array}$ \\
\hline P16 & $\mathrm{M}$ & Electrical engineer & Engineering & 2 & VLC & Energetics \\
\hline P17 & $\mathrm{M}$ & Head of production & Engineering & 1 & SMC & Sanitary products \\
\hline P18 & $\mathrm{M}$ & Entrepreneur & Skills training & 37 & $\mathrm{MC}$ & Agribusiness \\
\hline P19 & $\mathrm{F}$ & $\begin{array}{c}\text { Assistant } \\
\text { HR Manager }\end{array}$ & $\mathrm{Bac}+4$ & 30 & LC & Energetics \\
\hline P20 & M & technical Manager & Engineering & 10 & SMC & $\begin{array}{l}\text { Building / } \\
\text { Construction }\end{array}$ \\
\hline P21 & $\mathrm{M}$ & Maintenance Manager & Engineering & 1 & $\mathrm{MC}$ & Agribusiness \\
\hline P22 & $\mathrm{M}$ & Entrepreneur & Skills training & 25 & VSC & Agribusiness \\
\hline P23 & $\mathrm{M}$ & HR Manager & IBM Master & 34 & SMC & Mining \\
\hline P24 & $\mathrm{M}$ & HR Director & Ph.D. & 30 & SMC & Automotive \\
\hline P25 & M & $\begin{array}{c}\text { Head of Power } \\
\text { department }\end{array}$ & Engineering & 30 & VLC & Mining \\
\hline P26 & M & Technical Engineer & Engineering & 6 & VLC & $\begin{array}{l}\text { Building / } \\
\text { Construction }\end{array}$ \\
\hline $\mathrm{P} 27$ & $\mathrm{M}$ & QHSE Manager & Master's degree & 3 & $\mathrm{MC}$ & Agribusiness \\
\hline P28 & $\mathrm{M}$ & HR Manager & Master's degree & 27 & VLC & Mining \\
\hline P29 & $\mathrm{F}$ & Sales manager & Master's degree & 9 & $\mathrm{LC}$ & Automotive \\
\hline P30 & $\mathrm{F}$ & Assistant HR Manager & Master's degree & 10 & SMC & $\begin{array}{l}\text { Building / } \\
\text { Construction }\end{array}$ \\
\hline
\end{tabular}

Note: * VSC: Very small company: $1-10$ employees; ${ }^{*}$ SC: Small company: 10-49 employees; ${ }^{*}$ MC: Medium company: 50 - 499 employees; ${ }^{*}$ LC: Large company: 500-999 employees; ${ }^{*}$ VLC: Very large company: more than 1000 employee; ${ }^{*}$ SMC: Subsidiary of a multinational company

Sources: developed by the author. 
Other interviews were conducted based on telephone conversations or correspondences by e-mail in case the interviewee was not available to meet. In order to analyse qualitative data, a content analysis was adopted, whose purpose is «to provide knowledge and understanding regarding the phenomenon» (Downe-Wamboldt, 1992). The content analysis used combines categorical and evaluative analysis (Bardin, 1989). Indeed, when the categorical analysis fixes entities based on the frequency of themes' appearance, the purpose of the evaluative analysis is to «measure speaker's attitudes towards objects about which he is speaking» (Bardin, 1989). It is to identify indicators concerning the speaker's attitudes that are «behind the scattering of verbal manifestations» (Bardin, 1989). Hence, the logico-semantic analysis that combined treatment processes used by both evaluative and categorical analysis methods were adopted. As a first step, attitudes were identified. Since interviews are the semi-structured type, the attitudes play the role of categories which allow us to classify elements that constitute the message (Bardin, 1989). In the second step, defined units were counted based on the frequency of their presence. Thus, the third step concerned the analysis and interpretation of the obtained results. Indeed, after-cutting comments, spotting themes, classifying them into meaningful units, and counting their occurrence frequencies, the comments were set into several dimensions. The term "theme" to identify the cohesive set of answers that aggregates the observed trends in the data.

Results. Five main themes have emerged from data regarding weaknesses that are related to human resources management inside of Moroccan industrial companies. Table 2 provides a simple description of these themes that will be presented in detail later.

Table 2. Principal themes

\begin{tabular}{|c|c|c|}
\hline & Description & Comment example \\
\hline Theme 1 & HRF structuration & «I cannot speak of an HR function.» \\
\hline Theme 2 & $\begin{array}{l}\text { Misapplication of fundamental } \\
\text { Practices }\end{array}$ & «lt should be a specified department just for HR management» \\
\hline Theme 3 & Maturity in terms of management & «There is no Occupational Medicine System» \\
\hline Theme 4 & Staff motivation & $\begin{array}{l}\text { «Motivation of the company's executive should also be ensured» } \\
\text { «We recognize employees' efforts .... }\end{array}$ \\
\hline Theme 5 & Irrelevance of training & «Generally, recruits do not have enough solid basic training» \\
\hline
\end{tabular}

Sources: developed by the author.

Theme 1: HR function structuration. Through the interviews conducted, several respondents noted the lack of structuring at the HR function. As one respondent has mentioned: «In fact, I cannot speak about an HR function, because as an HR manager, I am just managing staff in its preliminary sense. In other words, the job is to check employee's presence, manage payroll and applications having a relationship with the staff, display ...». It felt that the awareness concerning the importance of the HR function contributes to the overall performance of the company was generally rare and often insufficient. As a participant pointed out, «We are rarely interested in assessing the contribution of the HR function in the organization's performance». However, the commitment of the high direction to provide a well-structured HR function can be considered as a standard in the other companies that have a long history in integrating their human resources in order to achieve their objectives.

Theme 2: misapplication of fundamental practices. The second theme that emerged is related to some fundamental misapplication of HRM practices. In this sense, it was clear that it is hard for some companies to apply their internal administrative procedures as a participant bearing witness: «Administrative procedures often cause cumulated delays», or as another also specified: "even if the procedures are generally clear and well structured, but they are often rigid while being applied....». Rigidity regarding administrative procedures application is often found in companies with rigid hierarchical cultures. Among the fundamental weaknesses of HRM, it was also revealed the problem of non-adequacy between the job 
and the person that is in charge of it. One participant commented: «We must give more importance to the adequacy Position / Person». Ensuring the adequacy Position / Person is one of the main tasks of any personnel management. Therefore, such weakness is a significant challenge that blocks companies' performance.

Theme 3: maturity in terms of management. The third theme focuses on emerging weaknesses related to maturity in terms of management practices. In connection with the occupational medicine which is considered as a maturity indicator in terms of HRM, one respondent said: «Occupational medicine system is manifested through a doctor who comes to visit the corporate site every Wednesday. So if an employee has a health problem he can consult the doctor who makes decisions regarding health care, and who decides to allow him to take some rest or to recommend that the employee changes his job inside the firm if his health case so requires». Another person reported, «we do not have metrological measures of risks that an employee may encounter within the company». Similar comments were frequently found particularly among small and medium-sized enterprises. Regarding strategic workforce planning, HR manager of a medium-sized company said: «The fact that our company has not yet exceeded the personnel management stage, so we do not apply strategic workforce planning because it requires the prior existence of certain conditions regarding the structuring of the HR function, management tools ... ». The testimony of this participant emphasized the existence of conditions while applying management methods. Another type of weakness that may negatively affect the maturity of HRM was related to the use of technology. In this sense, one interviewee noted: «All documentation is done by writing on records or reports, there is no data record using computer tools». Even in companies where there was a enough available computers, there was no guarantee that they are used for audio or video content delivery that can be used as traceability tool, or in order to develop management process that is used. In some cases, particularly for companies whose HR function is very advanced, some weaknesses in the management control system existed too. In this context, an engineer pointed out: «Even if I am a senior executive, I am rarely informed concerning the major strategic and direction policies related to HR function within the society». Such gaps are usually due to the rigidity in terms of management control, as they can be related to the company's internal culture as expressed by one participant: «l feel a lack of flexibility of the decisionmakers within our business».

Theme 4: staff motivation. Staff motivation was prominent in the discussions. Thus it was revealed, through interviews, the existence of a variety of staff motivation practice such as motivation based on remuneration as one respondent mentioned, «Among staff motivation methods used in our business, there is motivation by premiums: shift premium, the premium for job quality, and bonuses depending on work and objectives achieved by each employee». Some companies motivate their personal through professional promotion as affirmed by a participant, «There is also career evolution», or as explained by another «Internal recruitment also exists, so a member can have the opportunity to occupy a higher job position». In line with this, leadership is included: «We recognize the efforts of people, meetings are organized to resolve problems which promote team spirit», staff motivation through the organization social activities: «as part of creating a good working environment, we organize trips, outings, sports events between the staff of different services». The latter practice aims to create homogeneity among the company's members. Control and monitoring are also among the practices not to abandon «And there is control and supervision».

While seeking to discover the difficulties related to this theme, it turned out, in some cases that besides the need to ensure the employees' motivation, but there is the need to ensure the managers' as well, as one participant expressed «Staff motivation is strongly requested... Another thing is to focus more on the company's Executives motivation...». This idea seemed to be very important. Indeed, how can we expect from an unmotivated manager to succeed in motivating his collaborators? On the other hand, the lack in terms of commitment and sense of belonging among employees is another challenge for the 
company: «few employees are aware of the company's objectives, some of them seem interested to know them». Despite the variety of the process used to motivate and encourage, the scientists continue to investigate it. As part of this, a manager said: «Continuing his academic or professional training returns to the collaborator himself. In this context, it is not an encouragement or facilitation from his company to push him to pursue his studies». The lack of this kind of motivation is a loss because, in this case, the film misses the opportunity to benefit from a more skilled workforce. Other firms do not provide enough monitoring that is necessary to establish good employees' proposals: «Our company does not have a system that ensures monitoring or improving solutions proposed by some agents'». Such a situation blocks the development of the company, and therefore it reduces its profits as it may demotivate and discourage its staff.

Theme 5: the irrelevance of training. The fifth theme that emerged through this study is linked to problems related to the irrelevance of training received by recruits. As part of this, one participant expressed: "Generally, recruits do not have enough solid basic training to perform their duties within the company. Hence other training are usually needed before they can perform their jobs independently». In addition to the non-adequacy of basic knowledge acquired by the new employee, the problem of nonrelevance of training extends to those provided by the company itself.

Most training that companies provide in order to upgrade their employees does not match, in many cases, with the ambitions of decision-makers. The responsibility for this situation is shared. For example, if a company relies on another company to give a training to its staff, the company in charge does not provide reliable information in order to increase the employment chances to work repeatedly with the same company on the pretext of providing additional training. On the other hand, in many cases, companies' managers ensure the organization of training for the benefit of their employees, but they do not control the quality of the information provided by the company that is in charge of these training. Employees, in their turn, do not claim the irrelevance of training they receive. Based on the results found through this study, a set of proposals has been developed to enrich research within the few revealed HRM's characters used in the Moroccan context. These proposals have defended or argued many findings across the literature. Indeed, similar results were obtained by Kehri et al. (2010) when they asserted that «the size factor has a very significant influence on the organizational structure of the company [...]. In medium-sized companies, human resources function can only be a simple unit to perform daily administrative tasks. In large firms, the function takes a more sophisticated and more structured form». Trepe et al. (2010) defend the same idea. Despite dealing with few aspects related to companies maturity in general, the obtained results are adequate and accurate to perform the definition given by management; for example; communication constitutes a useful tool for accompanying changes within organizations (Fabi et al., 1999), or because excellent communication is recognized as an essential process to set in order to ensure the proper functioning of a work team (Chiocchio, 2012). Also, it was recognized that safety in workplaces affects staff behaviours (Troxel, 1954). Known scholars throughout the HRM literature have not just defended it, but it also pushes us to adopt the idea of «satisfaction mirror» through which Heintzman and Marson (2005) state links between employee satisfaction and quality of offered services, as declared McMahan et al. (1999) by relating developing employees skills to the increase in terms of organizational performance.

Regarding the increased need to pay more attention to effectiveness and efficiency within management systems adopted, Gilbert et al. (2007) rightly recall that a human resources policy is evaluated based on its achievements and not on the logic that would be effective, «A Human Resources policy is evaluated also based on the image that gives much importance to perceptions and value judgments (fairness, trust, modernity, etc.) than the efficiency logic». The efficiency concept was also defended through literature by several authors such as Ulrich (1997) and Boudreau et al. (2006).

The results found through this study confirm that the idea according to which older people develop a better adaptation to working conditions as demonstrated by Strivasta (1982), Lewis (1981) or Alderfer 
(1969) still able to argue. Indeed, investigation findings do not allow us to affirm the relationship between age and appreciating work's regulations. It cannot either state that this assessment is depending on the interviewee's sex as declared Spector (1997). Therefore, the results agree with those of Foucher (1980) when he considered that there is almost no relationship between age and job satisfaction while believing that, other intrinsic personal characteristics, or also those related to one's profession cannot be nuanced. It seems to be also true due to the rarity regarding systems interested in assessing their HR contribution in the organization's performance. Integration of IT tools as a solution. The solution for improving the situation of the studied enterprises is a proposition to give more importance to the integration of IT tools in the management processes. Indeed, the development of computer science has changed the practices of HRM over the world. It even plays a strategic and essential role in the HRM performance in firms located in developed countries. Information systems (IS) allow the storage of data on staff, facilitating the dissemination of information to authorized and concerned persons by HRM issues. It frees HR managers from administrative activities (often decentralized). Mainly, computerization contributes to: increasing productivity; improving service; developing the quality of HR decisions; sharing function between HR managers and hierarchy; anticipating relevant actions.

Moreno pointed out that according to Peretti (2008), human resources information systems (HRIS) are used in: payroll management; administrative management of staff; HRM through recruitment, training, payment for training, training report, remuneration, career, staff and position management, attendance and absenteeism management, individual social assessment, the company's social balance sheet, forward career management, etc.

Computerization plays a significant role in the evolution of HRM because it contributes to the sharing of the function, the personalization and the individualization of the HRM practices. The intranet facilitates communication and the transmission of information. As an example, the state of work attendance, absenteeism, management of leave and training sessions. The software packages which are proactive software allowing to record information, to capture it and to mobilize it in order to provide a result built in terms of HRM such as payroll or personnel management... Expert systems: based on data collected and then supplied to this software, the system develops responses by simulating the reasoning of an expert. Based on the above, the integration of information systems can effectively contribute to structuring the HR function through facilitating communication. They can also help to apply the fundamental practices thoroughly and improve the management methods of different HR aspects, as they can be used to relevant and various training while including the e-learning programs. It will motivate employees who search for developing their skills and competences.

Conclusions. This content analysis has identified some profound weaknesses. Indeed, a lack in terms of structuring HR function was revealed in addition to the non-adequacy between job requirements and the competences of the person in charge of this position, especially with the lack in terms of using developed managerial methods such as strategic workforce planning method, or within the absence of adopting occupational medicine system, or even in terms of maturity regarding the achievement of control system tasks, besides the weaknesses related to the absence of active communication, of clarity of objectives for all members, and sharing private information, without forgetting, of course, those resulting in the irrelevance of training received by staff. The use the information systems can effectively contribute to solving the found problems. Indeed, information systems promote active communication, different storage data that develop the quality of the decision. They also facilitate managing administrative issues, communicating and applying procedures, programming relevant training and motivating employees.

Author Contribution: Conceptualization, A. E. and C.M.; methodology, A. E. and C.M.; software, A. E.; validation, A. E. and C. M.; formal analysis, A. E.; investigation, A. E.; resources, A. E.; data curation, A.E.; writing-original draft preparation, A.E.; writing-review and editing, A.E.; visualization, A. E.; supervision, A. M.; project administration, S. E. 


\section{References}

Alderfer, C.P. (1969). An empirical test of a new theory of human needs. Organization behavior and human performance, 4(2),

142-175. [Google Scholar] [CrossRef]

Bardin, L. (1989). L'analyse de contenu (5e ed.). Paris: Presses Universitaires de France.

Berry, L. L. (1981). The employee as customer. Journal of retailing banking,3(1), 33-40.

Boudreau J. W., \& Ramstad P. M. (2006). Talentship and HR measurement and analysis: From ROI to strategic, human resource planning. Human resource planning, 29(1), 25-33.

Chester B. (1938). The function of executives, p. 139.

Chiocchio, F., Grenier, S., \& O', T. A. (2012). The effects of collaboration on performance: A multilevel validation in project teams. International Journal of Project Organisation and Management, 4(1), 1. [Google Scholar] [CrossRef]

Creswell, J. W. (2007). Qualitative inquiry and research design: Choosing among five approaches. Sage Publications.

DeRue, D. S., Hollenbeck, J., Ilgen, D., \& Feltz, D. (2010). Efficacy dispersion in teams: Moving beyond agreement and aggregation. Personnel Psychology, 63(1), 1-40. [Google Scholar] [CrossRef]

Downe-Wamboldt, B. (1992). Content analysis: method, applications, and issues. Health Care for Women International, 13(3), 313-321. [Google Scholar] [CrossRef]

Dul, J. \& Hak, T. (2007). Case study methodology in business research. Routledge. [Google Scholar]

Ely, M., Anzul, M., Friedman, T., \& Garner, D. (1991). Doing qualitative research: Circles within circles (Vol. 3). Psychology

Press. [Google Scholar]

Edmans, A. (2011). Does the stock market fully value intangibles? Employee satisfaction and equity prices. Journal of Financial economics, 101(3), 621-640. [Google Scholar] [CrossRef]

Fabi B., Martin Y., \& Valois P. (1999). Favoriser l'engagement organisationnel des personnes oeuvrant dans des organisation en transformation. GESTION -MONREAL, 24, 102-113.

Farnham, D. (2010). Human Resource Management in Context. (3rd Edition). McGraw-Hill Education.

Foucher, R. (1980). Concept et Mesure de la Satisfaction au Travail et des Besoins Relies au Travail: Applications aux Enseignants du Niveau Collegial Quebecois. Secteur Francophone, Thèse de doctorat en psychologier Inedit.

Gilbert P., Charpentier M., \& Layole G.(2007). Evaluation et pilotage de la performance RH. Donnez de l'intelligence à vos

tableaux de bord. Revue Entreprise \& Personnel.

Glesne, C., Peshkin,A. (1992). Becoming qualitative researchers:An introduction. White Plains, NY: Longman.

Hackman, J. R. (2012). From causes to conditions in group research. Journal of organizational Behavior, 33(3), 428-444 [Google Scholar] [CrossRef]

Heintzman R, \& Marson B,. (2005). People, service and trust: is there a public sector service value chain? International Review of Administrative Sciences, 71(4), 549-575. [Google Scholar] [CrossRef]

Heskett, J.L., JONES, T. O., Loveman, G. W., Sasser, W. E., \& Schlesinger, L. A. (1994). Putting the service profit chain to work. Harvard Business Review, 72(2), 164-174. [Google Scholar] Dalloz. Igalens, J. (1999). Satisfaction au travail. [auteur du livre] R Le Duff. Encyclopedie de la gestion et du management. Paris: Iglesias, K, Renaud, O., \& Tschan, F. (2010). La satisfaction au travail. Revue internationale de psychosociologie, 16(40), 245270. [Google Scholar] [CrossRef]

Jamshidian A., Izadian N., \& Shams Z. M. (2016). An evaluation of maturity of human resources management strategy based on philips model. Journal of Fundamental and Applied Sciences., 8(2S), 1546-1562.

Kehri, S. (2012). La problematique de l'integration strategique des Ressources Humaines dans l'entreprise algerienne. (Doctoral dissertation, Universite Mouloud Mammeri). [Google Scholar]

Laitinen, E.K. (2004). Nonfinancial factors as predictors of value creation: Finish evidence. Review of accounting and finance [Google Scholar] [CrossRef]

L'analyse de contenu au discours (2018). Retrieved from http://www.analyse-du-discours.com/l-analyse-de-contenu-du$\underline{\text { discours }}$

Lewis A. L. F. (1981). Job satisfaction, decisional discrepancy, academic social climate, and academic achievement in selected title i elementary schools. [Google Scholar]

Lincoln, Y. S. \& Guba, E.G. (1986). But is it rigorous? Trustworthiness and authenticity in naturalistic evaluation. New directions for program evaluation, 1986(30), 73-84. [Google Scholar] [CrossRef]

Luthans, F. (1998). Organizational Behavior. 8 Edition, McGraw-Hill, Boston, p.147

McMahan, G. C., Virick, M., \& Wright, P. M. (1999). Alternative theoretical perspectives for strategic human resource management revisited: Progress, problems, and prospects. Research in personnel and human resource management, 4(1), 99-122. Mellahi, K., Morrell, K., \& Wood, G. (2003). The ethical business: challenges and controversies. Macmillan International Higher Education. [Google Scholar]

Merriam, S. B. (1998). Qualitative Research and Case Study Applications in Education. Revised and Expanded from "Case Study Research in Education". Jossey-Bass Publishers, 350 Sansome St, San Francisco, CA 94104. [Google Scholar] 
Meyssonnier, R. \& Roger, A. (2006). L'impact du cocooning organisationnel et des opportunites d'emploi sur le lien entre satisfaction au travail et intention de quitter. XVIlème Congrès de l'AGRH, 16-17.

Mignonac, K. (2004), Que mesure-t-on reellement lorsque l'on invoque le concept de satisfaction au travail? Revue de gestion desrRessources humaines, (53), 80-93. [Google Scholar]

Miles, M., \& Huberman. A.M. (1984). Qualitative data analysis: A sourcebook of new methods. In Qualitative data analysis: a sourcebook of new methods. Sage publications. [Google Scholar]

Patterson, C. (2010). Business briefs: Business theory made easy. Ventus Publishing ApS. Retrieved from http://www.bookboon.com

Price, J. L. (2001). Reflections on the determinants of voluntary turnover. International Journal of manpowe. [Google Scholar] [CrossRef

Purcell, J., Kinnie, N., Hutchinson S., Rayton, B. \& Swart, J. (2003). Understanding the people and performance link: unlocking the black box. London: CIPD Publishing. [Google Scholar]

Spector, P.E. (1997). Job Satisfaction: Application Assessment, causes and consequences (Vol. 3). Sage Publications. [Google Scholar]

Strivasta S.K. (1982). Job satisfaction among private and public secondary school teachers. Perspectives in Psychological Research. [Google Scholar]

Thietart R.A. (2014). Methodes de recherche en management. Paris. Dunod. [Google Scholar]

Trepe, A., Aubert, P., Bermond, F., Carrère, J. M., Delanoue, M., \& Gouzi, B. (2010). L'evaluation de la performance de la fonction RH: De la theorie à la pratique des DG. Memoire d'expertise, universite de DAUPHINE, Paris. [Google Scholar]

Troxel, J. P. (1954). Elements in Job Satisfaction. Personnel, 31, 199-205.

Ulrich, D. (1997). Measuring human resources: an overview of practice and a prescription for results. Human Resource Management: Published in Cooperation with the School of Business Administration, The University of Michigan and in alliance with the Society of Human Resources Management, 36(3), 303-320. [Google Scholar]

Usunier, J.C. (1993). International Marketing: a cultural approach. Phillip Allan.

Wang, H., Sui, Y., Luthans, F., Wang, D., \& Wu, Y. (2014). Impact of authentic leadership on performance: Role of followers' positive psychological capital and relational processes. Journal of Organizational Behavior, 35(1), 5-21. [Google Scholar] [CrossRef]

Wacheux, F. (1996). Methodes qualitatives et recherche en gestion. (No. hal-00157140).

Ельмортада Асмаa, Ph.D., Університет Каді Аяд (Марокко):

Мохліс Чамс-Еддоха, Ph.D., професор, Університет Хасана II (Марокко);

Мохліс Ахмед, Ph.D., професор, Університет Каді Аяд (Марокко);

Ельфезазі Саїдб, Ph.D., професор, Університет Каді Аяд (Марокко).

Інновацій в управлінні персоналом: контент-аналіз

У статті зазначено, що одним із завдань управління людськими ресурсами (УЛР) $\epsilon$ підвищення рівня задоволеності умовами праці як менеджерів, так і працівників. Головною метою дослідження $є$ аналіз сучасних викликів, які постають перед менеджерами промислових підприємств при впровадженні практик УЛР у країнах, що розвиваються, на прикладі Марокко Методологія практико-орієнтованого дослідження базується на якісному методі, в основі якого лежить використання контентаналізу. Детерміновану вибірку даних сформовано на основі відповідей 30 менеджерів, які взяли участь у неформальному інтерв'ю. У статті проаналізовано рівень задоволеності менеджерів функціями УЛР, описано практики, які використовуються для мотивації працівників, виявлено слабкі місця та бар'єри, що знижують ефективність УЛР на промислових підприємствах Марокко. Отримані емпіричні результати дослідження свідчать, що найбільший негативний вплив на ефективність УЛР здійснюють такі фактори як: відсутність належної структурованості відділу кадрів; не розвиненість системи документообігу; некомпетентність працівників; відсутність ефективних методів управління. При цьому авторами зазначено, що для підвищення ефективності УЛР доцільним $\epsilon$ впровадження системи підвищення кваліфікації кадрів, розроблення системи охорони праці та системи контролю відповідності поставлених завдань, формування системи соціальної підтримки працівників пенсійного віку. У ході дослідження встановлено, що відсутність активного спілкування, чітких цілей, а також обмін недоцільною внутрішньою інформацією являються факторами-дестимуляторами ефеективності УЛР. Для вирішення визначених проблем авторами запропоновано впровадити інформаційне забезпечення УЛР та відповідні IT інструменти. У статті доведено, що інформаційні системи стимулюють активну комунікацію між працівниками, структуроване зберігання інформації та формування баз даних, що сприяє підвищенню якості прийнятих рішень. Авторами зазначено, що результати дослідження можуть бути корисними для спеціалістів відділу кадрів та керівників підприємств.

Ключові слова: управління людськими ресурсами, функції відділу кадрів, контент-аналіз, промислові підприємства, Марокко, задоволення умовами праці, ефективність функціонування відділу кадрів, інтеграція ІТ-інструментів, інформаційні системи, системи бази знань, взаємодія людина-комп'ютер.

Manuscript received: 03.12.2019.

(C) The author(s) 2020. This article is published with open access at Sumy State University. 